\title{
HLA-B27 DETERMINATION BY POLYMERASE CHAIN REACTION
}

\author{
D.C. KILPATRICK \\ Department of Transfusion Medicine, 2 Forrest Road, Edinburgh EHI 2QN, Scotland
}

\begin{abstract}
SUMMARY
A method for determining the presence or absence of HLA-B27 by selective amplification of a region in the third exon of the HLA-B27 gene common to $\mathrm{B} * 2701$ to $\mathrm{B} * 2705$ inclusive, was evaluated. This polymerase chain reaction/sequence specific primer (PCR-SSP) method gave perfect correlation with serological typing on 40 individuals of previously determined HLA type and on 50 further clinical samples evaluated blind. It was concluded that HLA-B27 determination by PCR-SSP is simple, reliable. cost-effective and convient for laboratory staff.
\end{abstract}

Key words HLA-B27 HLA disease associations Polymerase chain reaction

\section{INTRODUCTION}

HLA-B27 is a class 1 MHC antigen possesed by approximately $8 \%$ of Europeans (Tiwari and Terasaki, 1985). As a disease marker, it is very strongly associated with ankylosing spondylitis, Reiter's syndrome and acute anterior uveitis, conferring relative risks for those conditions of about 100, 40 and 10, respectively (Tiwari and Terasaki, 1985). Relationships with other forms of reactive arthritis, psoriatic arthropathy and arthritis with inflammatory bowel disease have also been reported. The term "seronegative spondylarthropathies" has been coined to cover the spectrum of diseases to which HLA-B27 has been linked. Determination of HLA-B27 status is of importance in the differential diagnosis of the rheumatic disorders.

At least nine separate genotypes code for polypeptides serologically identified as HLA-B27 (Lopez de Castro, 1994). The commonest is B*2705 which is found in approximately $90 \%$ of European B27-positive individuals; the remainder are almost entirely $B * 2702$. The genotypes $B * 2703$ and $B * 2704$ are common in negroid and oriental populations, respectively. $\mathrm{B} * 2706$ is found less frequently in Asian peoples and the other HLA-B27 genotypes are extremely rare. The typical disease associations are found with $B * 2701, B * 2702, B * 2704$ and B*2705 (MacLean, 1992), but not with B*2706 (LopezLarrea et al., 1995), while the status of $B * 2703$ is uncertain.

Determination of HLA-B27 at the DNA level is potentially more accurate and less expensive than serological tissue-typing and has the major practical advantage that there is no requirement for viable cells. The $B 27$ subtypes $B * 2701$ through to $B * 2705$ have a common amino acid sequence between residues 91 and 136 (Lopez de Castro, 1994), and therefore it should be possible to determine B27 status by selective amplification of codons 91 to 136 by polymerase chain reaction with sequence-specific primers (PCR-SSP). Here I describe an evaluation of this approach to routine HLAB27 determination. 


\section{METHODS}

\section{DNA preparation}

DNA was isolated from whole (anticoagulated) blood by a salting-out procedure using a commercial kit (Puregene DNA Isolation Kit, purchased from Flowgen Ltd., Sittingbourne).

\section{Primers}

The specific primers designed to hybridise with codons 91 to 97 and codons 131 to 135, respectively, of the third exon of the HLA-B27 gene were, E91s: GGGTCTCACACCCTCCAGATT and E136as: CGGCGGTCCAGGACCT (Dominguez et al., 1992). As internal controls, primers hybridising with a monomorphic region within the 3rd intron of the HLA-DR $\beta 1$ gene were used; C5: TGCCAAGTGGAGCACCCAA and C3: GCATCTTGCTCTGTGCAGAT (Olerup and Zetterquist, 1992).

\section{Polymerase chain reaction (PCR-SSP)}

Each PCR mixture (total volume $25 \mu \mathrm{l})$ contained specific primers $(1 \mu \mathrm{M})$, internal control primers $(0.2 \mu \mathrm{M})$, deoxynucleotide triphosphates $(200 \mu \mathrm{M}$ with respect to each), $\mathrm{MgCl}_{2}(1.5 \mathrm{mM}$ ) and 0.5 Units of Taq polymerase (Advanced Biotechnologies Ltd., Leatherhead, Surrey) in the supplier's reaction buffer. Each tube except the negative control also contained 200-400 ng of DNA. The PCR consisted of 33 cycles of (1) $95^{\circ} \mathrm{C}$ for $40 \mathrm{~s}$, (2) $63.5^{\circ} \mathrm{C}$ for $60 \mathrm{~s}$, and (3) $72^{\circ} \mathrm{C}$ for $60 \mathrm{~s}$, followed by a 10 minute extension period at $72^{\circ} \mathrm{C}$ in a Techne PHC-2 thermal cycler. The reaction products were visualised under $\mathrm{U}-\mathrm{V}$ illumination after electrophoresis in $2 \%$ agarose gels in 0.04 M-Tris/0.02 M-acetate/0.001 M-EDTA buffer, pH8.4, containing $0.5 \mu \mathrm{g} / \mathrm{ml}$ ethidium bromide

\section{Blood and DNA samples}

Blood samples from laboratory staff or patients (of known tissue type) obtained freshly or stored frozen, or DNA preparations previously made from peripheral blood and stored frozen, were used for the retrospective evaluation. For the prospective study, blood samples sent to the routine tissue-typing laboratory for HLA-B27 testing had aliquots removed for DNA preparation.

\section{Serological HLA-B27 determination}

Mononuclear cells prepared from heparinised blood were typed for HLA-B27 using the standard two stage microcytotoxicity test (Tiwari and Terasaki, 1985).

\section{RESULTS}

\section{Retrospective study}

DNA samples from 40 individuals whose full tissue-types were known were tested by PCR-SSP (Table 1). There was a perfect correlation between serological testing and group-specific genotyping. In every instance where HLA-B27 was present, the specific PCR signal (135 base pairs) was stronger than the internal control signal (Fig. 1). HLAB7 posistive samples were no different from other tissue-types. 
Table 1. Retrospective evaluation of HLA-B27 genotyping.

\begin{tabular}{lll}
\hline Category & & Number $(\%)$ positive \\
\hline Group 1: & $\begin{array}{l}\text { HLA-B27 positive } \\
(\mathrm{n}=10)\end{array}$ & $10(100)$ \\
Group 2: & $\begin{array}{l}\text { HLA-B7 positive, B27 negative } \\
(\mathrm{n}=10)\end{array}$ & 0 \\
Group 3: & $\begin{array}{l}\text { HLA-B7 and B27 negative } \\
(\mathrm{n}=20)\end{array}$ & 0 \\
\hline
\end{tabular}

\section{Prospective study}

Clinical samples on which an HLA-B27 test had been requested were tested independently by PCR-SSP and assigned positive or negative before the serological determination was ascertained. During this blind, prospective investigation all but one of the 50 samples tested yielded identical results by PCR-SSP and serology. (Seventeen samples were positive, and 32 were negative, by both methods). The exception was negative by serology, but gave a weak signal by PCR-SSP which was no stronger than the internal control signal. After this discrepancy was revealed, the same DNA sample and a new DNA preparation from the corresponding frozen blood sample were re-tested, and both were repeatedly found to be negative. Another sample had also given a doubtful positive reaction on first testing but was repeated and shown to be clearly negative before being assigned.

\section{DISCUSSION}

This PCR-SSP method of HLA-B27 determination may yield four possible outcomes. As well as clearly negative or positive, a failed test or a suspicious positive might be apparent. A "failed test" refers to the situation where neither specific nor control signals were obtained; this usuaily occured with samples taken several days before arriving in the laboratory. A "suspicious result" refers to a weak positive signal no stronger than the internal control signal. In both cases, the test should be repeated. These clear warnings of possible false negativity or false positivity are a major advantage of this system.

Although care is clearly needed to avoid contamination (and hence "suspicious results"), the PCR-SSP method is technically simple and well suited to routine tissuetyping laboratories. The data presented here provide evidence that this method is reliable and accurate. Moreover, the cost is comparable to that of serological testing, and the test can be repeated (if necessary) several times on a DNA preparation obtained from $0.3 \mathrm{ml}$ of anti-coagulated or even clotted blood. The biggest advantage of this method, however, is the convience to laboratory staff; there is no requirement for fresh preparation of viable cells, and indeed the DNA samples can be batched and tested together at a time suitable for the laboratory. 


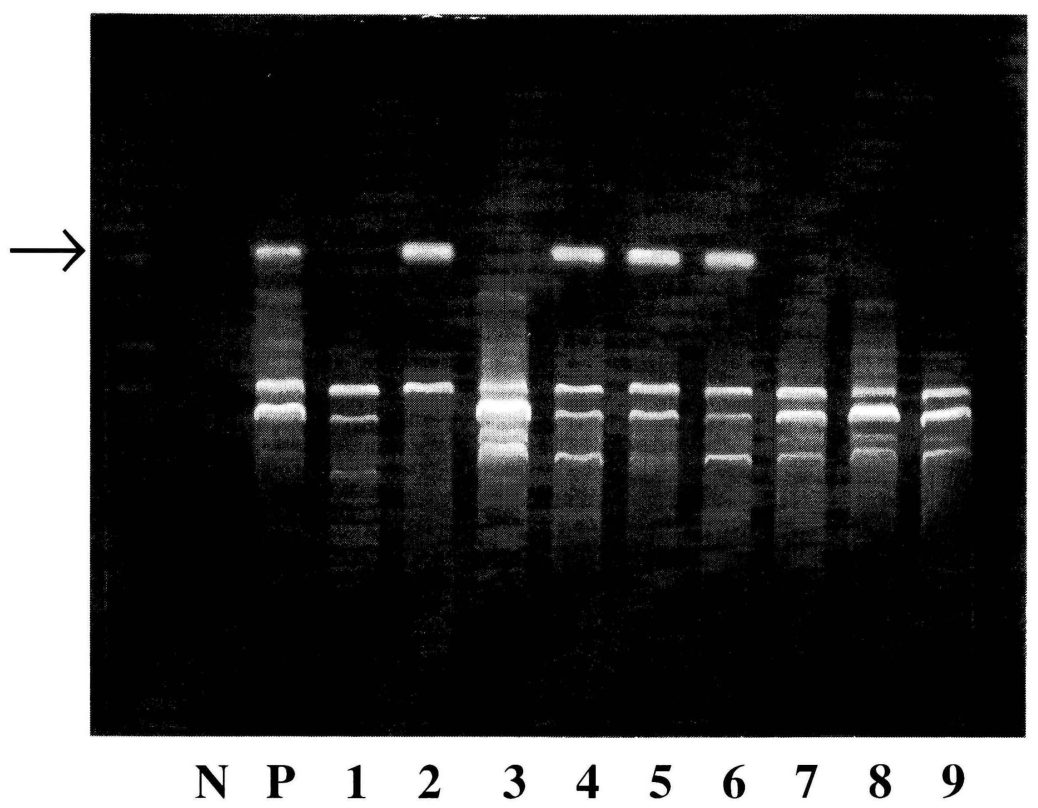

Figure 1. DNA typing for HLA-B27. PCR products were electrophoresed for $1 \mathrm{~h}$ at $50 \mathrm{~mA}(70 \mathrm{~V})$ as described in the Methods section. From left to right: molecular size markers of 50, 150 (indicated), 300, 500, 750 and 1000 base pairs; negative (no DNA) control (N); positive control (P); unknowns numbers 1 to 9 . Internal control bands are apparent in all samples at 800 base pair size and greater, but only unknowns 2, 4, 5 and 6 display the B27-specific signal at the 135 base pair position.

While this work was in progress, Olerup (1994) reported a similar strategy. In order to include the rare $\mathrm{B} * 2706$ and $\mathrm{B} * 2707$ genotypes, he chose to amplify a region in the second exon of the HLA-B27 gene. This required the introduction of a deliberate mismatch and resulted in a weak specific signal which benefited from enhancement by the addition of glycerol to the reaction mixture. It is not clear whether Olerup's system would as readily alert the technician to the possibility of a false positive result.

\section{ACKNOWLEDGEMENTS}

I thank the MLSO staff of the tissue-typing laboratory for providing blood samples and performing the serological tissue-typing. I also thank Dr. T. Paterson for synthesising the oligonucleotide primers used.

\section{REFERENCES}

Dominguez, O., Coto, E., Martinez-Naves, E., Choo, S.Y., Larrea-López, C. (1992). Molecular typing of HLA-B27 alleles. Immunogenetics, 36, 277-282.

López de Castro J.A. (1994). Structure, function, and disease association of HLA-B27. Curr. Opin. Rheumatol., 6, 371-377. 
Lopez-Larrea, C., Sujirachato, K., Mehra, N.K. et al. (1995). HLA-B27 subtypes in Asian patients with ankylosing spondylitis. Tissue Antigens, 45, 169-176.

MacLean, L. (1992). HLA-B27 subtypes: implications for the spondyloarthropathies. Ann. Rheum. Dis., 51, 929-931.

Olerup, O. (1994). HLA-B27 typing by a group-specific PCR amplification. Tissue Antigens, 43, 253-256.

Olerup, O., Zetterquist, H. (1992). HLA-DR typing by PCR amplification with sequence-specific primers (PCR-SSP) in 2 hours: an alternative to serological DR typing in clinical practice including donor-recipient matching in cadaveric transplantation. Tissue Antigens, 39, 225-235. Tiwari, J.L., Terasaki, P.I. (1985). HLA and Disease Associations, Springer-Verlag, New York. 


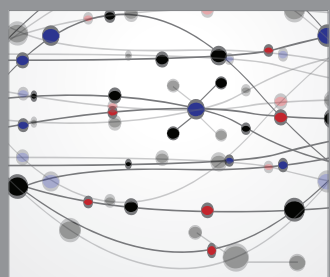

The Scientific World Journal
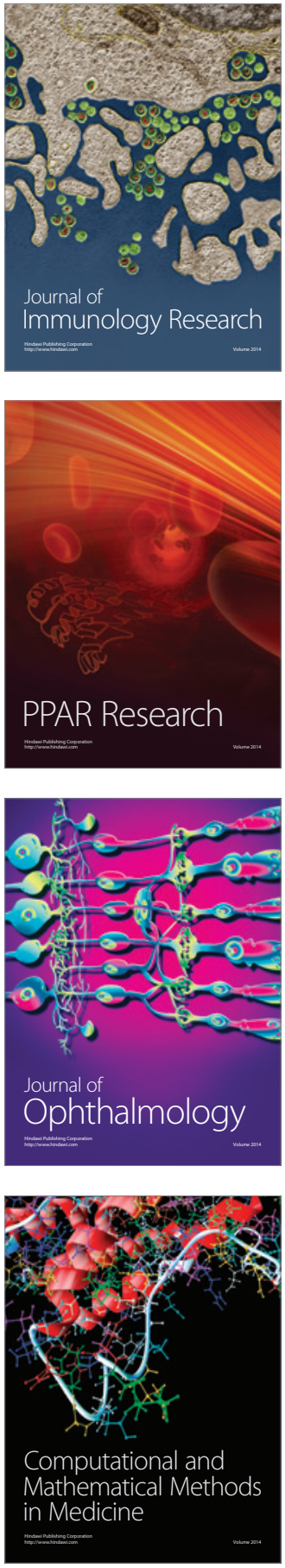

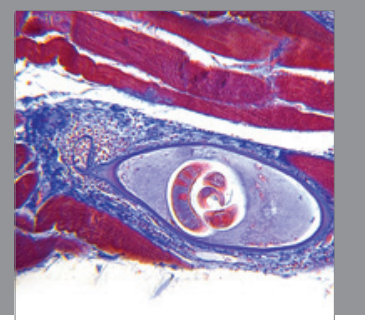

Gastroenterology

Research and Practice
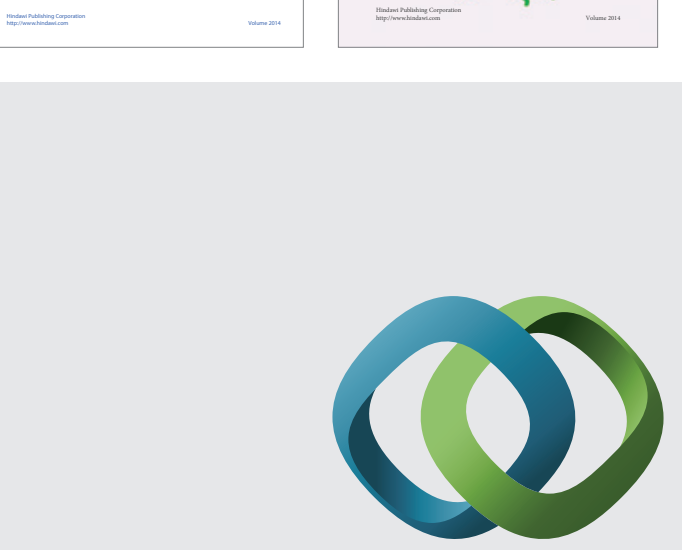

\section{Hindawi}

Submit your manuscripts at

http://www.hindawi.com
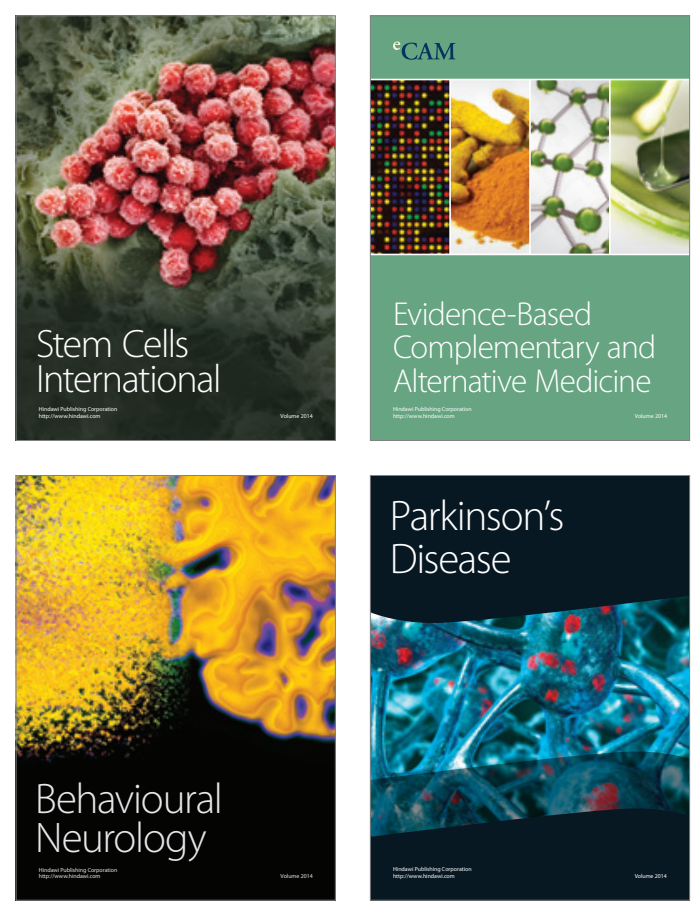

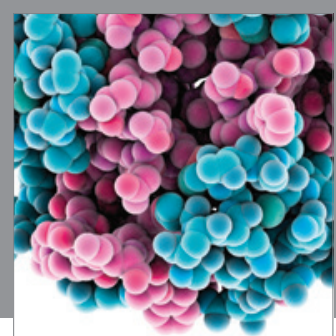

Journal of
Diabetes Research

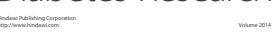

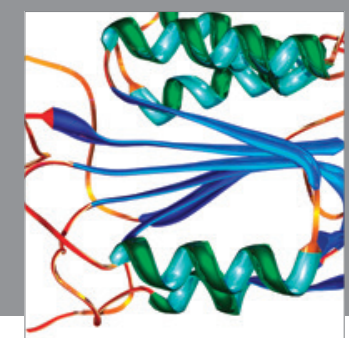

Disease Markers
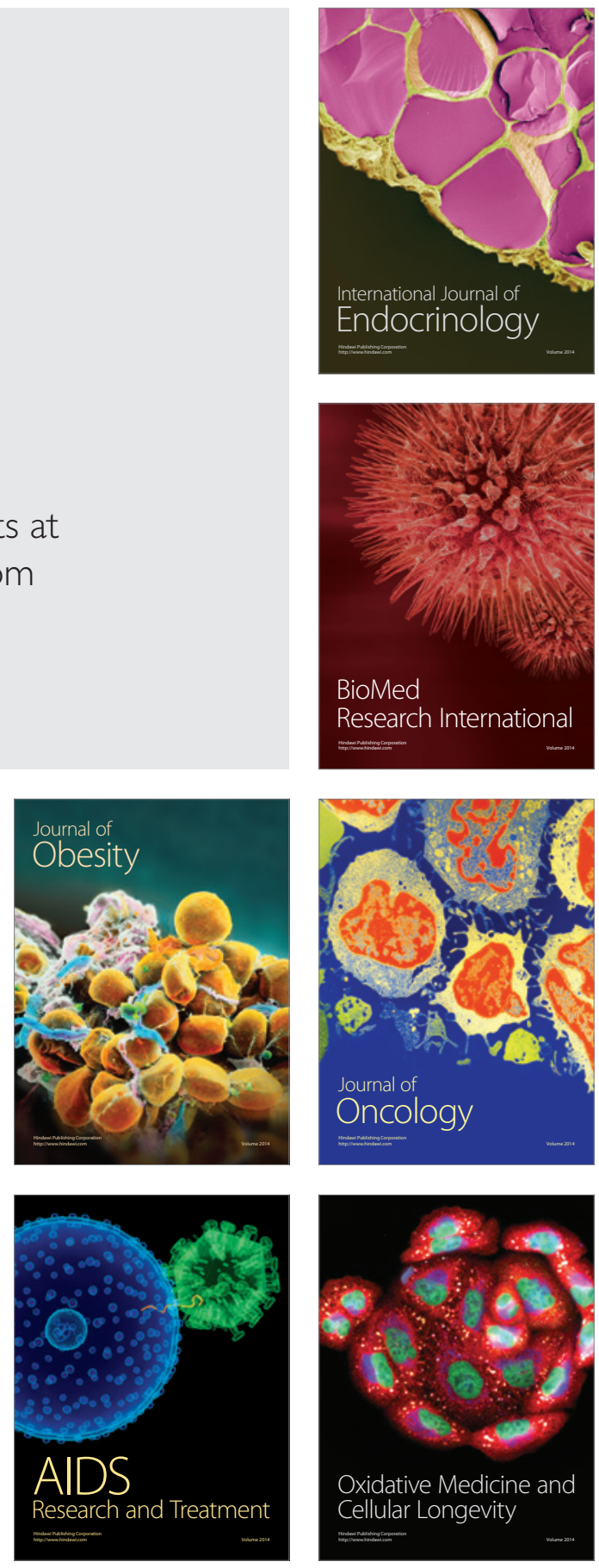